\title{
A MULTIIZZNE MODEL OF THE COMBUSTION PROCESS IN AN SI ENGINE AS AN EXTERNAL CYLINDER OF THE GT-POWER SIMULATION TOOL
}

\section{JIŘi HVĚZDA}

Josef Božek Vehicle Centre for Sustainable Mobility

Czech Technical University in Prague, Technická 4, 16607 Praha 6, Czech Republic, E-mail: jiri.hvezda@fs.cvut.cz

\section{SHRNUTI}

Příspěvek představuje obecnou proceduru týkající se implementace uživatelského modelu jako externího válce simulačního nástroje GT-Power.

Konkrétně, vyvinutý vícezónový model vysokotlaké části termodynamického cyklu čtyřdobého spalovacího motoru je zde použit jako přizpůsobený simulační kód pro zajištění výpočtů souvisejících s chemickou transformací spalování, přestupem tepla a odpovídajícími stavovými veličinami.

Jsou zde prezentovány vybrané technické podrobnosti a výsledky tohoto propojení.

KLIČOVÁ SLOVA: SIMULACE, SPALOVÁNÍ, VÍCEZÓNOVÝ MODEL, UŽIVATELSKÝ MODEL, EXTERNÍ VÁLEC, GT-POWER

\section{ABSTRACT}

The paper introduces a generalized procedure dealing with an implementation of the user model as an external cylinder of the GT-Power simulation tool.

In this case, the developed multi-zone model of the high-pressure part of the thermodynamic cycle in a four-stroke combustion engine is used as a customized simulation code to treat the calculations regarding combustion chemical transformation, heat transfer and corresponding state quantities.

Selected technical details and results of this coupling are presented here.

KEYWORDS: SIMULATION, COMBUSTION, MULTI-ZONE MODEL, USER MODEL, EXTERNAL CYLINDER, GT-POWER

\section{INTRODUCTION}

A multi-zone model of combustion and heat transfer processes was presented in [1] as an interesting alternative for simulation of the high-pressure part of the working cycle of a four-stroke spark ignition engine.

A differential-algebraic equation system was derived, based on the law of conservation of mass, the law of conservation of energy, the state equation and empirical equations for calculation of heat transfer coefficient and turbulent flame velocity, to describe a multi-zone model of combustion and heat transfer processes in a spark ignition engine.

The generalized procedure for participation of chemical kinetics and chemical equilibrium was introduced here to address the numerical issues connected with a purely kinetic scheme.

At this moment, there are two options to cover all geometrical requirements of the equation system describing the multi-zone model. Both are created using the AutoLisp programming language to be able to generate solids of particular zones for the given combustion chamber geometry and to create data files with geometrical characteristics containing corresponding volumes and areas. The first one is a customized code for real combustion chamber geometry. The second is a GeoGen parametric generator equipped with the basic combustion chamber shapes.

As a result, a numerical tool with the following features was created:

- initially focused on direct spark ignition engines

- settles the numerical issues regarding the chemical transformation of fuel

- takes into account a real combustion chamber geometry

- works with a predictive as well as inverse algorithm

- can be implemented as a user's model in a complex combustion engine simulating tool 


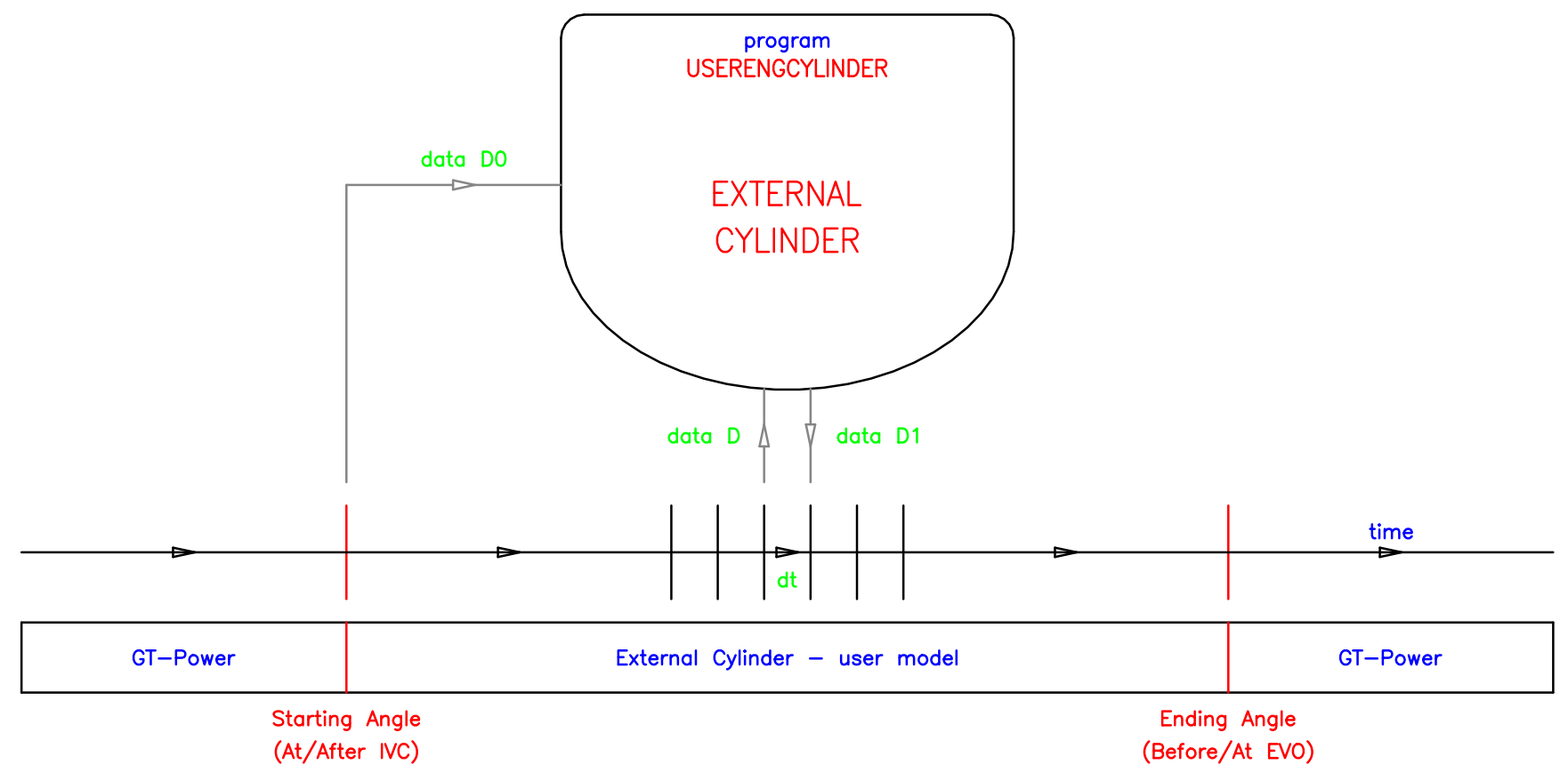

FIGURE 1: Time diagram of external cylinder

OBRÁZEK 1: Časový diagram externího válce

- has potential to improve the study of knocking phenomenon and its prediction

- provides for easy calibration using experimental data and its extrapolation

- is fast in order to save on computational time

- is sufficiently accurate

- reflects the user's low hardware and software capacities

- has the ability to be expanded to the area of prechamber spark ignition engines, dual fuel and compression ignition engines

For the meaningful utilization of this code, its implementation into a superior and complex simulator, which will solve the following tasks outside the high-pressure part of working cycle and outside the combustion chamber, is necessary.

- cylinder charge exchange reflecting the timing and discharging characteristics of the valve system

- transfer of in-cylinder pressure to the crankshaft mechanical power in terms of crank mechanism and engine mechanical efficiency

- discharge conditions of the inlet and exhaust manifold

- potential combustion engine supercharging

- fuel system

With the aid of prepared user models, this option is offered here using the simulation tool GT-Power [2], which is able to transfer the calculations of all events during combustion to the external solver.

\section{GT-POWER USER MODELS - EXTERNAL CYLINDER}

GT-Power as a complex combustion engine simulation tool offers the ability to implement a user's own programs. These models developed by the user, called "user models" or "user routines", can be integrated into GT-Power in order to meet the userspecified requirements in modeling certain physical or generic processes. User models may be inserted by adding a user's own code replacing any of the standard GT-Power sub-models.

User routines are not actually used in the simulation unless they are specifically invoked from a template in the GT-Power model. There are a number of templates that let users integrate their own routines and maintain the communication between GT-Power and these routines without leaving GT-Power during the simulation.

GTI provides the source files for the user subroutines, which are written in Fortran. Moreover, these source files are arranged in project workspace by means of the SLN file. This prepared area is to be modified in Microsoft Visual Studio coupled with Intel Fortran Compiler to create a DLL library, which is accessed by GT-Power at each computational time step.

In the case of the external cylinder user model, the external code is used for in-cylinder modeling at specified crank angles between IVC (intake valve closure) and EVO (exhaust valve opening). At the beginning of this area (at or after IVC), some initial case parameters (engine speed, angular step of numerical 
solution, piston, head and liner surface temperatures, etc.) are transferred as data D0 from GT-Power to the external cylinder.

Subsequently, at each computational time step up to the end of external simulation (before or at EVO), the following input data $\mathrm{D}$ are transferred from GT-Power:

- crank angle

- in-cylinder pressure

- in-cylinder temperature

- cylinder charge mass

- chemical species mass fractions

to provide the external calculations, which are responsible for the changes of pressure, temperature, species concentrations and corresponding heat transfers to obtain the following output data D1 to be transferred to GT-Power:

- in-cylinder pressure

- in-cylinder temperature

- chemical species mass fractions

- heat transfer rates to piston, head and liner

- cumulative fraction of burned fuel

- fraction of fuel burned during a step

This approach is shown schematically in (Figure 1).

\section{EXPANDED PROGRAM STRUCTURE OF THE MULTI-ZONE MODEL}

Prepared GT-Power Fortran source file EngCylinder_External. for representing the user model of external cylinder USERENGCYLINDER is modified to provide communication between GT-Power and the multi-zone model, and to assure the following functions:

- input data transfer from GT-Power

- definition of model parameters

- download of data files containing geometrical characteristics of the combustion chamber

- record of zone model results to data files

- output data transfer to GT-Power

However, the simulation of the high-pressure part of the working cycle of a four-stroke spark ignition engine by means of the multi-zone model of combustion and heat transfer processes is provided by the expanded program structure shown in (Figure 2). Particular program parts assure the following functions here:

- Subroutine EULER implements the applied numerical solution method - the second order Eulerian method. Its objective is to provide the particular step of the numerical solution, whereby it calls on other required procedures to convert input data D to output data D1.

- Subroutine CALLV returns the values of geometrical characteristics of type volume (zone volume and total volume) corresponding to actual crankshaft angle and spherical border surface radii.
- Subroutine CALLS returns the values of geometrical characteristics of type surface (heat transfer areas between zones and the parts creating the combustion chamber border) corresponding to actual crankshaft angle and spherical border surface radii.

- Subroutine CALLB returns the values of geometrical characteristics of type border (areas of borders between zones) corresponding to actual crankshaft angle and spherical border surface radii.

- Subroutine CALLR is partly inverted to the function of subroutines CALLV, CALLS and CALLB. Values of geometrical characteristics of type radius corresponding to new crankshaft angle and new zone volumes at the end of the numerical solution step are returned here.

- The objective of subroutine CAPACITY is to return the values of specific heat capacities at constant pressure as a function of temperature for all involved chemical species.

- The objective of subroutine ENTHALPY is to return the values of specific absolute enthalpies as a function of temperature for all involved chemical species.

- Subroutine TEMPERATURE is used for determination of mean thermodynamic temperature in the combustion chamber using an iterative procedure for this purpose.

- For a given moment, subroutine RHS determines the values of right-hand sides of differential equations and subsequently the values of time derivatives of mass vector, thermodynamic temperatures and pressure.

- The objective of VELOCITY subroutine is evaluation of turbulent flame velocity on the basis of an empirical approach.

- Subroutine KINETICS is responsible for the kinetic part of the chemical transformation of fuel leading to the production rates for all chemical species. Moreover, abnormally fast chemical reactions are excluded here to prepare a set of corresponding chemical components for equilibrium state determination.

- Subroutine THERM contains the chemical kinetic and thermodynamic data for a given reaction mechanism.

- Subroutine EQUILIBRIUM provides a method for obtaining the chemical composition corresponding to the state of chemical equilibrium for particular initial molar quantities, pressure and temperature.

- Subroutine GAUSSJ is a standard program for solving a linear algebraic equation system using the GaussJordan elimination method.

- The objective of subroutine GIBBS is to return the values of dimensionless free enthalpy function determined from the Gibbs free enthalpies as functions of temperature for all involved chemical species. 


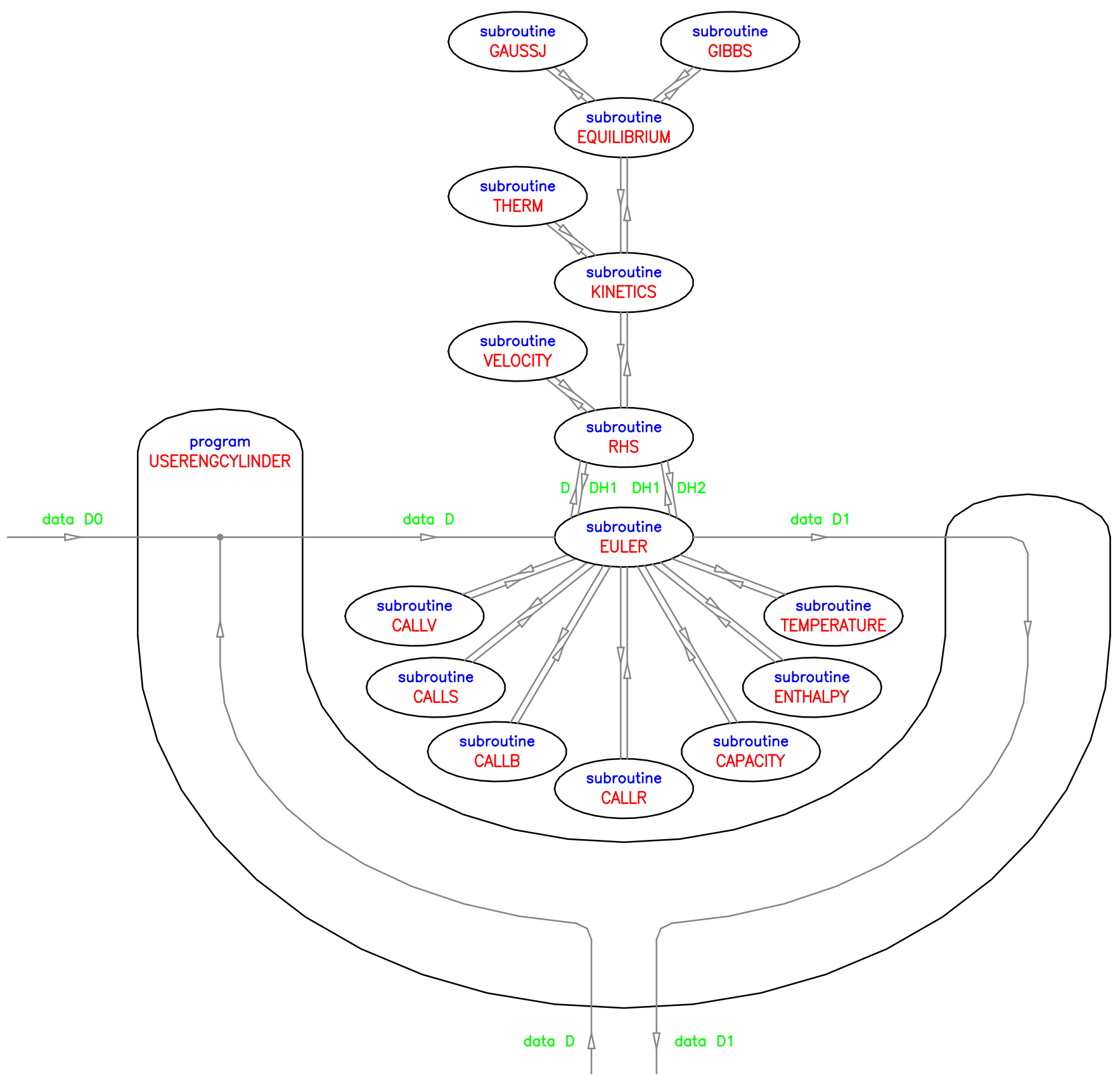

FIGURE 2: Multi-zone model program structure

OBRÁZEK 2: Programová struktura vícezónového modelu

\section{RESULTS}

The functionality of the above introduced coupling between the GT-Power complex simulation tool and an external cylinder user model represented by the multi-zone model of combustion and heat transfer processes in SI engines was checked.

For this purpose, a simplified GT-Power engine model, shown in (Figure 3), consisting of inlet and exhaust manifold, fuel injector, inlet and exhaust valve, one cylinder and crank mechanism was selected.
On the other hand, the most complicated version of the predictive version of the multi-zone model dealing with adaptive algorithm combining chemical kinetics and equilibrium was used here with a reaction mechanism belonging to hydrogen combustion. The complete mechanism of this chemical transformation consists of 23 reactions involving 11 species. The following detailed reaction mechanism description and corresponding chemical kinetic and thermodynamic data are obtained by means of [3]: 


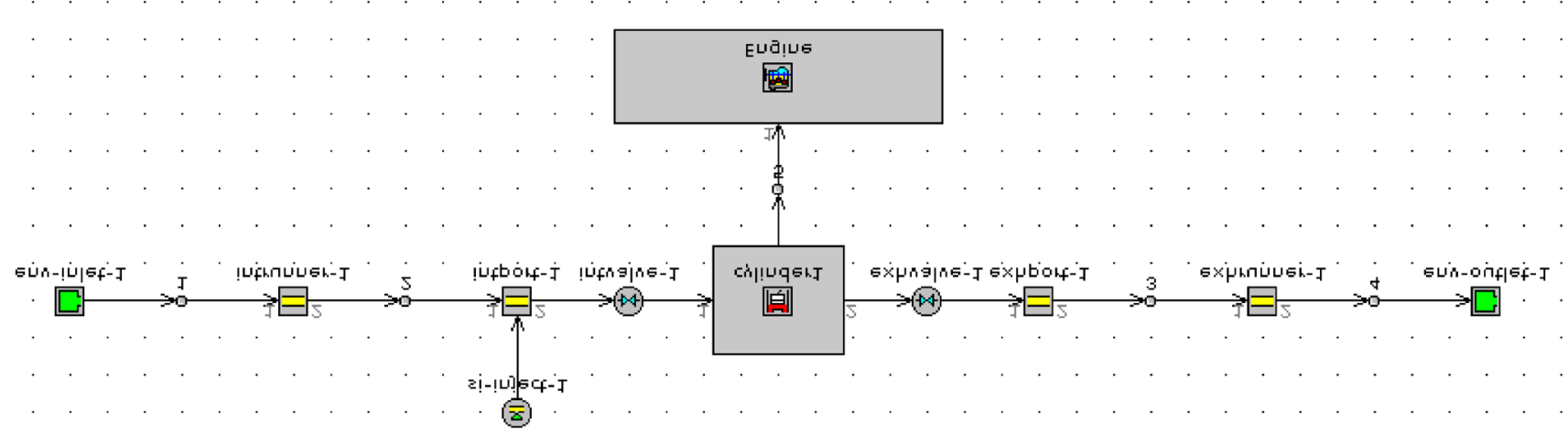

FIGURE 3: GT-Power engine model

OBRÁZEK 3: GT-Power model motoru

$\begin{array}{ll}01 & \mathrm{H} 2+\mathrm{O} 2=2 \mathrm{OH} \\ 02 & \mathrm{OH}+\mathrm{H} 2=\mathrm{H} 2 \mathrm{O}+\mathrm{H} \\ 03 & \mathrm{O}+\mathrm{OH}=\mathrm{O} 2+\mathrm{H} \\ 04 & \mathrm{O}+\mathrm{H} 2=\mathrm{OH}+\mathrm{H} \\ 05 & \mathrm{H}+\mathrm{O} 2+\mathrm{M}=\mathrm{HO} 2+\mathrm{M} \\ 06 & \mathrm{OH}+\mathrm{HO} 2=\mathrm{H} 2 \mathrm{O}+\mathrm{O} 2 \\ 07 & \mathrm{H}+\mathrm{HO} 2=2 \mathrm{OH} \\ 08 & \mathrm{O}+\mathrm{HO} 2=\mathrm{O} 2+\mathrm{OH} \\ 09 & 2 \mathrm{OH}=\mathrm{O}+\mathrm{H} 2 \mathrm{O} \\ 10 & 2 \mathrm{H}+\mathrm{M}=\mathrm{H} 2+\mathrm{M} \\ 11 & 2 \mathrm{H}+\mathrm{H} 2=2 \mathrm{H} 2 \\ 12 & 2 \mathrm{H}+\mathrm{H} 2 \mathrm{O}=\mathrm{H} 2+\mathrm{H} 2 \mathrm{O} \\ 13 & \mathrm{H}+\mathrm{OH}+\mathrm{M}=\mathrm{H} 2 \mathrm{O}+\mathrm{M} \\ 14 & \mathrm{H}+\mathrm{O}+\mathrm{M}=\mathrm{OH}+\mathrm{M} \\ 15 & 2 \mathrm{O}+\mathrm{M}=\mathrm{O} 2+\mathrm{M} \\ 16 & \mathrm{H}+\mathrm{HO} 2=\mathrm{H} 2+\mathrm{O} 2 \\ 17 & 2 \mathrm{HO} 2=\mathrm{H} 2 \mathrm{O} 2+\mathrm{O} 2 \\ 18 & \mathrm{H} 2 \mathrm{O} 2+\mathrm{M}=2 \mathrm{OH}+\mathrm{M} \\ 19 & \mathrm{H} 2 \mathrm{O} 2+\mathrm{H}=\mathrm{HO} 2+\mathrm{H} 2 \\ 20 & \mathrm{H} 2 \mathrm{O} 2+\mathrm{OH}=\mathrm{H} 2 \mathrm{O}+\mathrm{HO} 2 \\ 21 & \mathrm{O}+\mathrm{N} 2=\mathrm{NO}+\mathrm{N} \\ 22 & \mathrm{~N}+\mathrm{O} 2=\mathrm{NO}+\mathrm{O} \\ 23 & \mathrm{OH}+\mathrm{N}=\mathrm{NO}+\mathrm{H}\end{array}$
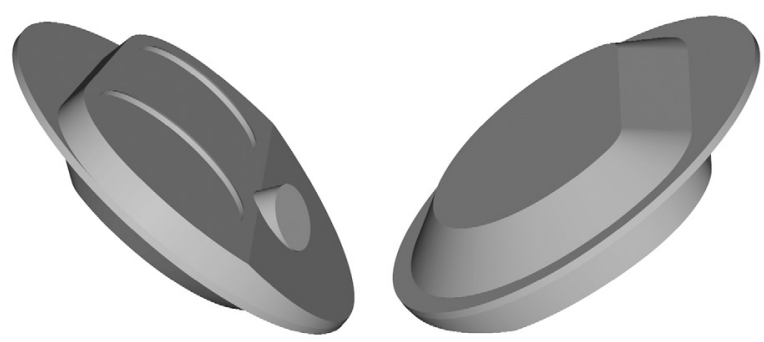

FIGURE 4: Compression volume of the ŠKODA engine OBRÁZEK 4: Kompresní objem motoru ŠKODA
At the end, four cases of one simulation task with variable mixture air-excess ratio and the following features were calculated. Due to the hydrogen type of fuel, no experimental data are available here for comparisons.

- ŠKODA hydrogen engine

- 2V cylinder head version

- Cylinder bore / piston stroke 76.5 / $86.9 \mathrm{~mm}$

- Compression ratio 10.3

- Real combustion chamber geometry (Figure 4)

- Mixture air-excess ratio: Case $1-0.9$, Case 2-1.0, Case $3-1.2$, Case $4-1.4$

- Ignition angle -15 degrees

- Turbulent coefficient 1.95

- Engine speed $3600 \mathrm{rpm}$

- Heat transfer coefficient - Eichelberg's equation

- Chemical equilibrium + chemical kinetics approach

The plots of combustion pressures for all four cases are shown in (Figure 5). Higher values of mixture air-excess ratio lead to lower combustion pressure. On the other hand, mixture air-excess ratio of 0.9 doesn't bring higher combustion pressure due to the lack of oxidizer.

Zone and mean temperature trends for Case 2 are presented in (Figure 6). There is an evident temperature rise in the fresh mixture area (zone 1) caused by its compression by combustion products expansion in the flame front (zone 2) and the combustion products region (zone 3 ). Pressure and temperature values from zone 1 can be used for a sub-model concerning knocking prediction.

The plots of combustion chamber and zone volumes for Case 2 are presented in (Figure 7). Here for the case of the three-zone model, a fresh mixture area (zone 1) is transformed sequentially to a flame front (zone 2) and combustion products region (zone 3) during the expansion stroke. Combustion chamber total volume depends just on piston kinematics. Here, quite a wide flame front (zone 2) is embodied, which doesn't correspond 


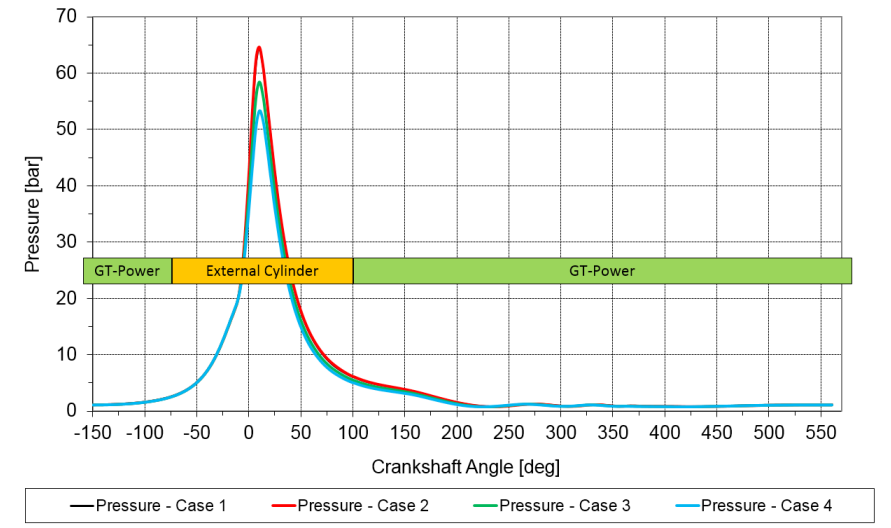

FIGURE 5: In-cylinder pressure

OBRÁZEK 5: Tlak ve válci

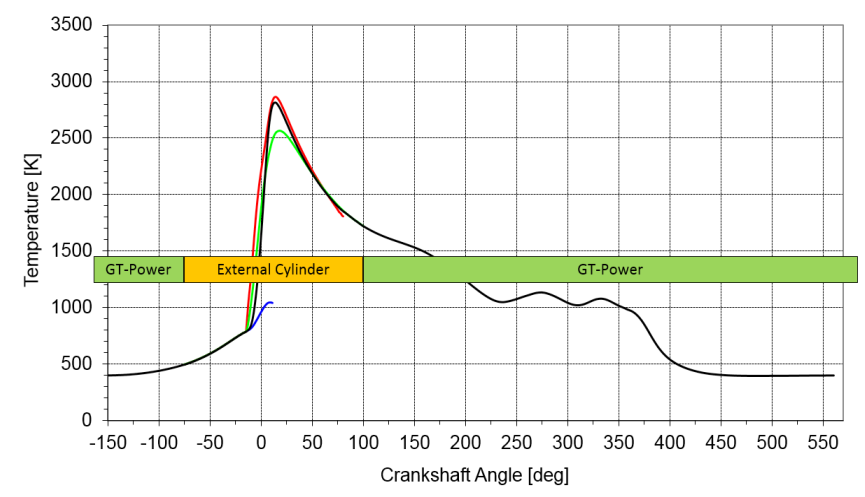

-Temperature - Zone 1 -Temperature - Zone 2 -Temperature - Zone 3 -Temperature - Mean

FIGURE 6: Zone and mean temperatures

OBRÁZEK 6: Zónové a střední teploty

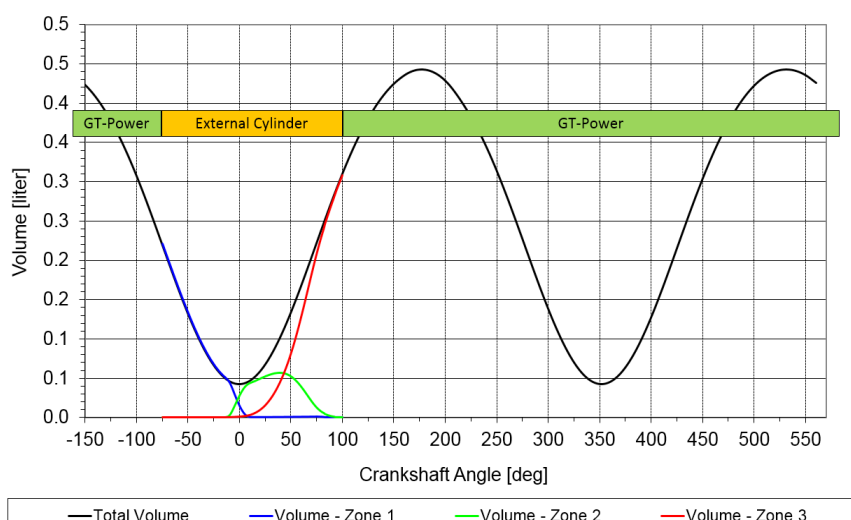

FIGURE 7: Combustion chamber and zone volumes

OBRÁZEK 7: Objemy spalovacího prostoru a zón

with general expectations concerning spark ignition combustion engines. This fact should be a matter of further improvements of the multi-zone model.

The crankshaft angle intervals from -75 to +100 degrees, where the external cylinder is responsible for all in-cylinder simulations, are marked in these figures.
The plots of ROB and ROHR curves and their cumulative values for Case 2 are shown in (Figure 8). Fuel consumption and heat release corresponding to the post combustion processes and chemical equilibrium establishment can be seen clearly here.

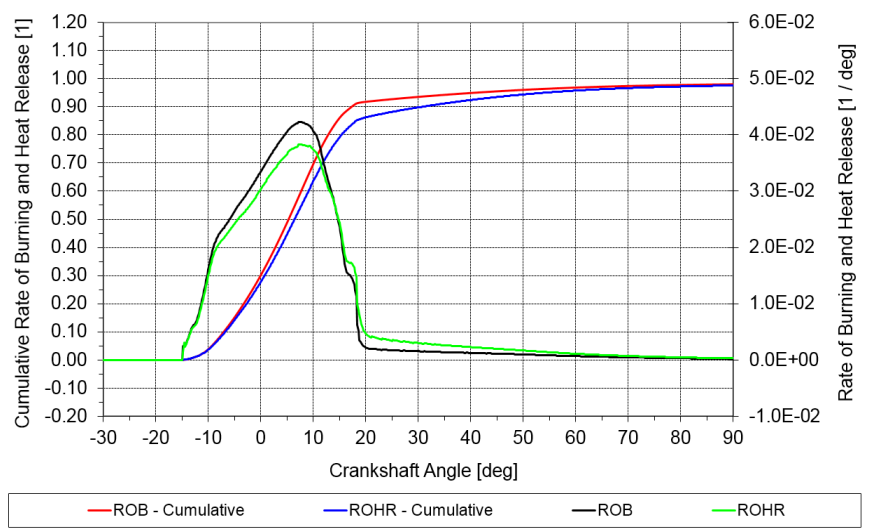

FIGURE 8: ROB and ROHR and their cumulative curves OBRÁZEK 8: Křivky ROB a ROHR and jejich kumulační křivky

Molar concentration trends for particular species during the combustion of a stoichiometric mixture (Case 2) are shown in (Figure 9). The equilibrium amounts of fuel $\mathrm{H}_{2}$ and oxidizer $\mathrm{O}_{2}$ corresponding to a stoichiometric ratio of fuel-oxidizer mixture are achieved here. The high flame temperature causes a sizable content of dissociated gases, monoatomic 0 in the range of $10 \mathrm{E}-4$, monoatomic $\mathrm{H}$ in the range of $10 \mathrm{E}-5$. The equilibrium amount of hydroxyl radical $\mathrm{OH}$ reaches the range of $10 \mathrm{E}-3$. Also, the activity of the Zeldovich mechanism, represented by the last three reactions of the reaction mechanism, is supported by high temperature leading to a content of nitric oxide $\mathrm{NO}$ in the range of 10E-3. Note that this amount comes from chemical kinetics only, as the reactions producing nitric oxide NO are almost never excluded from the reaction mechanism due to their high reaction rates.

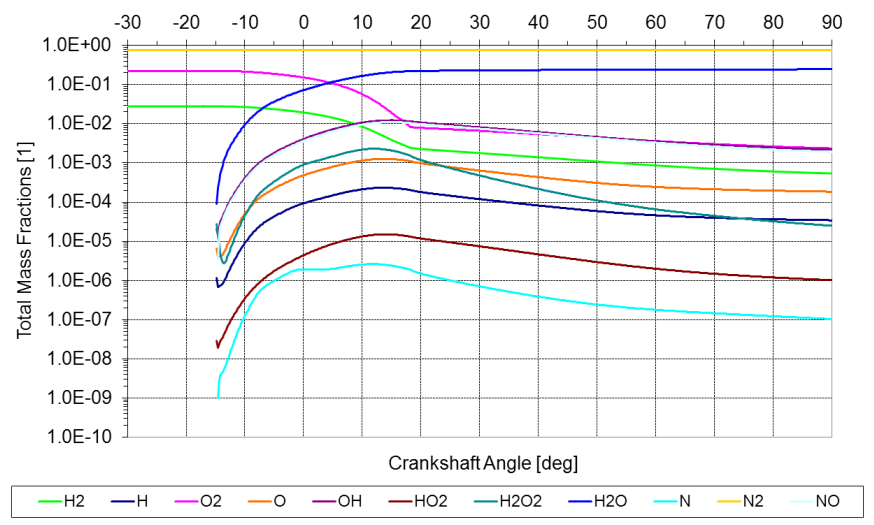

FIGURE 9: Molar fractions OBRÁZEK 9: Molární zlomky 


\section{CONCLUSION}

The multi-zone model of combustion and heat transfer processes was successfully integrated into the GT-Power complex combustion engine simulation tool as a user model of an external cylinder. Here, it is responsible for all calculations within a defined crankshaft angle range of the high-pressure part of the working cycle of a four-stroke spark ignition engine.

Thus, the complexity of GT-Power code is combined with the advantages of a zone approach presented at the beginning of this paper, specifically in the areas of engine knocking prediction, chemical transformation of fuel and real combustion chamber geometry reflection. Moreover, these advantages are not outweighed by a significant increase in computational time, which remains in the order of units of seconds for the given version of models.

User models preparation from GT-Power creators, their activation by the setting of appropriate blocks and templates, modification of Fortran source files including expansion of program structure by means of the own subroutines and final compilation into the functional DLL library was proved to be a successful method.

The above presented results confirm the ability of an external cylinder user model to read the input data from GT-Power to provide its own calculations, which are responsible for the changes of pressure, temperatures, species concentrations and corresponding heat transfers, and return these outputs back to GT-Power.

For now, all these points belong to the predictive version of simulation. An inverse algorithm allowing interesting evaluation of experimental data is mentioned here as a commitment for the near future.

\section{ACKNOWLEDGEMENTS}

This research has been realized using the support of EU Regional Development Fund in OP R\&D for Innovations (OP VaVpl) and Ministry for Education, Czech Republic, project \# CZ.1.05/2.1.00/03.0125 Acquisition of Technology for Vehicle Centre of Sustainable Mobility and the support of Technological Agency, Czech Republic, programme Centres of Competence, project \# TE01020020 Josef Bozek Competence Centre for Automotive Industry.

These supports are gratefully acknowledged.

\section{REFERENCES}

[1] Hvězda J., Multi-Zone Models of Combustion and Heat Transfer Processes in SI Engine, SAE 2014 World Congress, SAE Paper 2014-01-1067, 2014.

[2] GT-Power, User's Manual and Tutorial, GT-Suite TM version 6.2., Gamma Technologies Inc., 2006.

[3] Kee R. J., Rupley F. M., Miller J. A., Coltrin M. E., Grcar J. F., Meeks E., Moffat H. K., Lutz A. E., Dixon-Lewis G., Smooke M. D., Warnatz J., Evans G. H., Larson R. S., Mitchell R. E., Petzold L. R., Reynolds W. C., Caracotsios M., Stewart W. E., Glarborg P., Wang C., Adigun 0., CHEMKIN Collection, Release 3.6, Reaction Design, Inc., San Diego, CA 2000. 